\title{
Preliminary Phytochemical Screening and Antidiarrheal Properties of Manniophyton fulvum.
}

\author{
Ojieh E. Anthony ${ }^{1 *}$, Adegor C. Ese ${ }^{1}$, Ovuakporaye I. Simon ${ }^{1}$, \\ Ewhre O. Lawrence ${ }^{2}$ \\ ${ }^{1}$ Department of Physiology, Faculty of Basic Medical Sciences, Delta State University, Abraka, Nigeria \\ ${ }^{2}$ Department of Pharmacology and Therapeutics, Faculty of Basic Medical Sciences, Delta State University, \\ Abraka, and Emma-maria Biomedic Laboratories \& Consultancy, Abraka, Nigeria.
}

\begin{abstract}
The genus Manniophytum Fulvum belongs to the family of Euphorbiaceae, which is geographically distributed widely in tropical Africa. It has been investigated for a number of properties, such as analgesia, anti-inflammation and as remedy for cough, dysentery, haemorrhoids and haemoptysis.

Aims: This study investigates the phytochemical composition and antidiarrheal properties of the plant.

Methodology: Aqueous and ethanol leaves extracts of Manniophyton fulvum was prepared and used for the experiment. During the entire period of study the animals were supplied with standard pellet diet and water ad libitum. The animal experimentation was carried out accordance to the guidelines of Institutional Animal Ethics Committee (IAEC).

Results: Phytochemical studies carried out on aqueous and ethanol extract of Manniophyton fulvum leaves showed the presence of alkaloid, saponin, phenol, tannin, flavonoid, cardiac glycoside, steroid, phytosterol, triterpenoid and phlobatannin. The aqueous and ethanol leaves extracts of Manniophyton fulvum showed significant $(p<0.05)$ antidiarrheal activity on gastrointestinal motility with barium sulfate milk and castor oilinduced diarrheal model in rats.

Conclusion: These result obtained in this study, suggest that the leaves extract possess pharmacological activity against diarrhea and may find a place in the management of illness that present with diarrheal.

Keywords: Antidiarrheal activity, Barium sulfate milk, Castor oil, Manniophyton fulvum, Phytochemistry.
\end{abstract}

\section{Introduction}

Disease conditions that has diarrheal presenting as one of the symptoms are one of the leading causes of morbidity and mortality in developing countries especially amongst children and are responsible for the death of millions of people each year. (1). Despite immense technological advancement in modern medicine, many people in the developing countries still rely on medicinal plants for their daily health care needs (2). Therefore, the World Health Organization encouraged studies leading to the treatment and prevention of diarrheal diseases using herbs. (3).

Manniophyton fulvum, belongs to the family Euphorbiaceae, made up of shrubs or climber of about $30 \mathrm{~m}$. The flowers are usually pale to yellow in colour, and the genus is made up of approximately 20 species. Manniophyton Fulvum is a widely used locally in Nigeria for both therapeutic and nutritional purposes. It grows in a range of ecological zones in Africa and produces large mass forage and is drought tolerant, (4). The macerated leaves of the plants are consumed as vegetables and condiments while the water extract serves as tonic for the prevention of certain illnesses, (5).

Manniophyton fulvum has been studied and found to possess several therapeutic properties, like antiviral, antioxidant, antibiotic, wound healing and anti-inflammatory activity (5). This study was carried out to investigate Manniophyton fulvum for diarrheal properties following its use in the management of diarrheal amongst the Urhobos, Isokos and Beni people of Delta and Edo states, Niger Delta, Nigerian folklore medicine using various models.

\subsection{Plant Material}

\section{Materials and Methods}

Manniophyton fulvum leaves were collected from the wide growing habitat in Ethiope West Delta State, Nigeria. The leaves were removed from the stalk and air dried at room temperature $\left(22 \pm 2^{\circ} \mathrm{C}\right)$, to a constant weight after which it was grounded with sterilized machine and sieved to fine powder and made into extracts used for the experiment, (6). 


\subsection{Preparation of the Extracts}

The powder was weighed $(600 \mathrm{~g})$. The powder was divided into two equal part and soaked in $1500 \mathrm{ml}$ distilled water and $1500 \mathrm{ml}$ of ethanol respectively, for $72 \mathrm{hrs}$. The extract was obtained using an electrical evaporator extraction apparatus (rotary evaporator). The solvent was extracted at a temperature of $45^{\circ} \mathrm{C}$ and pressure of $60 \mathrm{~cm}$ of water. Paste- like extract was obtained and oven dried to complete solid and grinded to smooth powdered form, (6).

\subsection{Qualitative Phytochemical Analysis}

The powdered material and extract of the plants were subjected to different kinds of chemical tests to investigate the presence of secondary metabolites such as saponins, tannins, flavonoids, phenol, anthraquinones cyanogenic glycosides, cardiac glycosides and alkaloids using standard procedures $(7,8,9,10,11)$.

\subsection{Test for Proteins}

\subsubsection{Millon's test}

Crude extract when mixed with $2 \mathrm{ml}$ of Millon's reagent, white precipitate appeared which turned red upon gentle heating that confirmed the presence of protein.

\subsection{Test for Carbohydrates}

\subsubsection{Fehling's test}

Equal volume of Fehling A and Fehling B reagents were mixed together and $2 \mathrm{ml}$ of it was added to crude extract and gently boiled. A brick red precipitate appeared at the bottom of the test tube indicated the presence of reducing sugars.

\subsection{Iodine Test}

Crude extract was mixed with $2 \mathrm{ml}$ of iodine solution. A dark blue or purple coloration indicated the presence of the carbohydrate.

\subsection{Test for Phenols and Tannins}

Crude extract was mixed with $2 \mathrm{ml}$ of $2 \%$ solution of $\mathrm{FeCl} 3$. A blue-green or black coloration indicated the presence of phenols and tannins.

\subsection{Test for Flavonoids}

\subsubsection{Shinoda test}

Crude extract was mixed with few fragments of magnesium ribbon and concentrated $\mathrm{HCl}$ was added drop wise. Pink scarlet colour appeared after few minutes which indicated the presence of flavonoids.

\subsection{Alkaline Reagent Test}

Crude extract was mixed with $2 \mathrm{ml}$ of $2 \%$ solution of $\mathrm{NaOH}$. An intense yellow colour was formed which turned colourless on addition of few drops of diluted acid which indicated the presence of flavonoids.

\subsubsection{Test for phytosterol}

The extract was refluxed with solution of alcoholic potassium hydroxide till complete saponification takes place. The mixture was diluted and extracted with ether. The ether layer was evaporated and the residue was tested for the presence of phytosterol.

The residue was dissolved in few drops of diluted acetic acid; $3 \mathrm{ml}$ of acetic anhydride was added followed by few drops of Concentrated H2SO4. Appearance of bluish green colour showed the presence of phytosterol.

\subsubsection{Test for triterpenoids}

$10 \mathrm{mg}$ of the extract was dissolved in $1 \mathrm{ml}$ of chloroform, $1 \mathrm{ml}$ of acetic anhydride was added followed by addition of $2 \mathrm{ml}$ of Concentrated $\mathrm{H} 2 \mathrm{SO} 4$. Formation of reddish violet colour indicates the presence of triterpenoids.

\subsubsection{Test for phlobatannins}

About $2 \mathrm{ml}$ of aqueous extract was added to $2 \mathrm{ml}$ of $1 \% \mathrm{HCl}$ and the mixture was boiled. Deposition of a red precipitate was taken as an evidence for the presence of phlobatannins.

\subsubsection{Test for saponins}

Crude extract was mixed with $5 \mathrm{ml}$ of distilled water in a test tube and it was shaken vigorously. The formation of stable foam was taken as an indication for the presence of saponins. 


\subsubsection{Test for glycosides}

Liebermann's test: Crude extract was mixed with each of $2 \mathrm{ml}$ of chloroform and $2 \mathrm{ml}$ of acetic acid. The mixture was cooled in ice. Carefully concentrated $\mathrm{H} 2 \mathrm{SO} 4$ was added. A colour change from violet to blue to green indicated the presence of steroidal nucleus, that is, glycone portion of glycoside.

\subsubsection{Keller-kilani test}

Crude extract was mixed with $2 \mathrm{ml}$ of glacial acetic acid containing 1-2 drops of $2 \%$ solution of $\mathrm{FeCl} 3$. The mixture was then poured into another test tube containing $2 \mathrm{ml}$ of concentrated $\mathrm{H} 2 \mathrm{SO} 4$. A brown ring at the interphase indicated the presence of cardiac glycosides.

\subsubsection{Test for steroid}

Crude extract was mixed with $2 \mathrm{ml}$ of chloroform and concentrated $\mathrm{H} 2 \mathrm{SO} 4$ was added sidewise. A red colour produced in the lower chloroform layer indicated the presence of steroids. Another test was performed by mixing crude extract with $2 \mathrm{ml}$ of chloroform. Then $2 \mathrm{ml}$ of each of concentrated $\mathrm{H} 2 \mathrm{SO} 4$ and acetic acid were poured into the mixture. The development of a greenish coloration indicated the presence of steroids.

\subsubsection{Test for terpenoids}

Crude extract was dissolved in $2 \mathrm{ml}$ of chloroform and evaporated to dryness. To this, $2 \mathrm{ml}$ of concentrated $\mathrm{H} 2 \mathrm{SO} 4$ was added and heated for about 2 minutes. A grayish colour indicated the presence of terpenoids.

\subsubsection{Test for alkaloids}

Crude extract was mixed with $2 \mathrm{ml}$ of $1 \% \mathrm{HCl}$ and heated gently. Mayer's and Wagner's reagents were then added to the mixture. Turbidity of the resulting precipitate was taken as evidence for the presence of alkaloids.

\subsection{Quantitative Determination of the Chemical Constituent 2.10.1 Preparation of fat free sample \\ $2 \mathrm{~g}$ of the sample were defatted with $100 \mathrm{ml}$ of diethyl ether using a soxhlet apparatus for 2 hours.}

\subsubsection{Determination of total phenols by spectrophotometric method}

The fat free sample was boiled with $50 \mathrm{ml}$ of ether for the extraction of the phenolic component for 15 min. $5 \mathrm{ml}$ of the extract was pipetted into a $50 \mathrm{ml}$ flask, then $10 \mathrm{ml}$ of distilled water was added. $2 \mathrm{ml}$ of ammonium hydroxide solution and $5 \mathrm{ml}$ of concentrated amylalcohol were also added. The samples were made up to mark and left to react for $30 \mathrm{~min}$ for colour development. This was measured at $505 \mathrm{~nm}$.

\subsubsection{Alkaloid determination using Harborne (1973) method}

$5 \mathrm{~g}$ of the sample was weighed into a $250 \mathrm{ml}$ beaker and $200 \mathrm{ml}$ of $10 \%$ acetic acid in ethanol was added and covered and allowed to stand for 4 hours. This was filtered and the extract was concentrated on a water bath to one-quarter of the original volume. Concentrated ammonium hydroxide was added drop wise to the extract until the precipitation was complete. The whole solution was allowed to settle and the precipitated was collected and washed with dilute ammonium hydroxide and then filtered. The residue is the alkaloid, which was dried and weighed.

\subsubsection{Tannin determination by Van-Burden and Robinson (1981) method}

$500 \mathrm{mg}$ of the sample was weighed into a $50 \mathrm{ml}$ plastic bottle. $50 \mathrm{ml}$ of distilled water was added and shaken for 1 hour in a mechanical shaker. This was filtered into a $50 \mathrm{ml}$ volumetric flask and made up to the mark. Then $5 \mathrm{ml}$ of the filtered was pipetted out into a test tube and mixed with $2 \mathrm{ml}$ of $0.1 \mathrm{M} \mathrm{FeCl}$ in $0 . \mathrm{I} \mathrm{M} \mathrm{HCl}$ and $0.008 \mathrm{M}$ potassium ferrocyanide. The absorbance was measured at $120 \mathrm{~nm}$ within $10 \mathrm{~min}$.

\subsubsection{Saponin determination}

The samples were ground and $20 \mathrm{~g}$ of each were put into a conical aqueous and ethanol. The samples were heated over a hot water bath for $4 \mathrm{~h}$ with continuous stirring at about 5 another $200 \mathrm{ml} 20 \%$ ethanol. The combined extracts were red at about $90^{\circ} \mathrm{C}$. The concentrate was transferred into a $250 \mathrm{ml}$ separatory funnel and $20 \mathrm{ml}$ of diethyl ether was added and shaken vigorously.

The aqueous layer was recovered while the ether layer was discarded. The purification process was repeated. $60 \mathrm{ml}$ of washed twice with $10 \mathrm{ml}$ of $5 \%$ aqueous sodium chloride. The remaining solution was heated in a waterbath. After evaporation the samples were dried in the oven to a cons weight; the saponin content was calculated as percentage. 


\subsubsection{Flavonoid determination by the method of Bohm and KocipaiAbyazan (1974)}

$10 \mathrm{~g}$ of the plant sample was extracted room temperature. The whole solution was filtered through Whatman filter $\mathrm{mm}$ ). The filtrate was later transferred into a water bath and weighed to a constant weight.

\subsection{Animals and diet}

Male albino rats obtained from the animal house of Emma-maria Biomedic Laboratories \& Consultancy, Abraka, weighing between 120-150 g was used for the study. The rats were housed in a wellventilated animal unit provided by the Department of Pharmacology, Delta State University, Abraka, $\left(21 \pm 2^{\circ} \mathrm{C}\right.$, relative humidity $60-70 \%, 12 \mathrm{hr}$ light/ dark cycle). The rats were fed standard grower mash diet mixed with charcoal in a ratio of $2: 1$ (Composition of the grower's marsh: Protein -19.0\% Fat $-2.85 \%$ Fibre $-6.00 \%$ Calcium $-1.00 \%$ Available phosphate $-0.45 \%$ Energy -2875 KGC purchased from Animal Care Services Konsult NIG. LTD, Asaba, Delta State and water ad libitum. Permission for the use of animals and animal protocol was obtained from the Research ethics committee of Delta State University, Abraka and the laboratory animal ethics guideline was followed (6).

\subsection{Gastrointestinal motility test with barium sulfate milk}

The experiment was carried out by the method described by Chatterjee (14). Over night fasted twenty wistar albino rats were randomly divided in to four equal groups $(\mathrm{n}=5)$. All the animals in each group was given $2 \mathrm{ml}$ of $10 \%$ barium sulfate solution and 30mins after, the negetive Control group was given only distilled water $2 \mathrm{~mL} / \mathrm{rat}$ orally. Positive control group received commercially available anti diarrheal drug loperamide $1 \mathrm{mg} / \mathrm{kg}$ orally while the treatment groups received Manniophyton fulvum leaves aqueous and ethanol extracts $400 \mathrm{mg} / \mathrm{kg}$ orally. At the expiration of another $30 \mathrm{mins}$, all the rats were sacrificed by cervical dislocation, the abdomen opened and the total length of the small intestine measured with a calibrated ruler. The distance travelled by the charcoal stained meal (chyme) from the pylorus to caecum was determined and expressed as a percentage of the total length of the small intestine. Also the percent inhibition of movement was calculated for both the positive control and the treatment groups.

\subsection{Castor oil-induced diarrhea}

Castor oil-induced diarrhea model was carried out using the method described by Shoba and Thomas (15). twenty Wistar albino rats were randomly divided in to four equal group $(n=5)$. Negative control group, positive control group and treatment group respectively. The negetive control group received only distilled water $2 \mathrm{~mL} / \mathrm{rat}$, Positive control group received loperamide $1 \mathrm{mg} / \mathrm{kg}$ as standard while the treatment groups received Manniophyton fulvum leaves extracts at the dose $400 \mathrm{mg} / \mathrm{kg}$ body weight aqueous and ethanol extract. The rats were housed in separate cages having paper placed below for collection of fecal matters. Diarrhea was induced in rats by oral administration of castor oil $(1.0 \mathrm{ml} / \mathrm{rat})$. Extracts and drugs were given orally 1 hour before the administration of standard dose of $1.0 \mathrm{ml}$ of castor oil.

The number of both hard and soft pellet was counted at every hour over 6 hour period for each rat. Diarrhea was defined as the presence in the stool with fluid material that stained the paper placed beneath the cages. Percent inhibition (PI) was calculated as follows:

$\mathrm{PI}=\quad$ Mean defecation (Control group - Treated group $) \times 100$ Mean defecation of control group

\subsection{Statistical analysis}

The result of this study were expressed as mean + SEM, and were analyzed by one way analyses of variance (ANOVA) using statistical package for social science (SPSS, 20). Difference between the means were tested with post Hoc- LSD test for multiple comparison and significance was considered when $\mathrm{p}<0.01$. Student's dependent t-test was used to analyze the significant difference between the groups.

\section{Results And Discussion}

Table 1: Qualitative analysis of the aqueous and ethanol extract of Manniophyton fulvum leaves

\begin{tabular}{|l|l|l|}
\hline Chemicals & Aqueous extract & Ethanol extract \\
\hline Alkaloids & +++ & +++ \\
\hline Saponins & +-- & ++- \\
\hline Tannins & +++ & ++- \\
\hline Flavonoids & +++ & +++ \\
\hline Phenol & +++ & +++ \\
\hline Anthraquinones & ++- & ++- \\
\hline Cardiac glycosides & ++- & +++ \\
\hline Steroid & ++- & ++- \\
\hline Terpenoids & ++- & ++- \\
\hline
\end{tabular}


Preliminary Phytochemical Screening and Antidiarrheal Properties of Manniophyton fulvum.

\begin{tabular}{|l|l|l|}
\hline phytosterol & +-- & ++- \\
\hline triterpenoids & ++- & ++- \\
\hline Phlobatannins & ++- & +++ \\
\hline
\end{tabular}

Keys: +++ Abundantly present

++ - Moderately present

+ - - Present in trace amount

Table 2: Quantitative analysis of the aqueous and ethanol extract of Manniophyton fulvum leaves

\begin{tabular}{|l|l|l|}
\hline Chemicals & Aqueous extract & Ethanol extract \\
\hline Alkaloids & $2.3 \%$ & $1.9 \%$ \\
\hline Saponins & $2.5 \%$ & $3.3 \%$ \\
\hline Tannins & $2.3 \%$ & $3.18 \%$ \\
\hline Flavonoids & $6.8 \%$ & $7.6 \%$ \\
\hline Phenol & $6.0 \%$ & $6.9 \%$ \\
\hline
\end{tabular}

Phytochemical analysis conducted on the Manniophyton fuvum extracts revealed the presence of constituents which are known to exhibit medicinal as well as physiological activities similar to the study done by Aiyegroro and Okoh (16). Analysis of the plant extracts revealed the presence of phytochemicals such as phenols, tannins, flavonoids, saponins, glycosides, steroids, terpenoids, and alkaloids (Tables 1 and 2).

The phenolic compounds are one of the largest and most ubiquitous groups of plant metabolites (17). They possess biological properties such as anti-apoptosis, anti-aging, anticarcinogen, anti-inflammation, antiatherosclerosis, cardiovascular protection and improvement of endothelial function, as well as inhibition of angiogenesis and cell proliferation activities (18). Several studies have described the antioxidant properties of medicinal plants which are rich in phenolic compounds (19). Natural antioxidant mainly comes from plants in the form of phenolic compounds such as flavonoid, phenolic acids, tocopherols etc. (20). Tannins bind to proline rich protein and interfere with protein synthesis. Flavonoids are hydroxylated phenolic substances known to be synthesized by plants in response to microbial infection and they have been found to be antimicrobial substances against wide array of microorganisms in vitro (18). Their activity is probably due to their ability to complex with extracellular and soluble proteins and to complex with bacterial cell wall, (21).

Triterpenoids are terpenoid derivatives of triterpene molecules. They may have useful anticancer properties, (22). They also are effective antioxidant and show strong anti- cancer activities (23).

The plant extracts were also revealed to contain saponins which are known to produce inhibitory effect on inflammation (24). Saponins has the property of precipitating and coagulating red blood cells. Some of the characteristics of saponins include formation of foams in aqueous solutions, hemolytic activity, cholesterol binding properties and bitterness (25).

Steroids have been reported to have antibacterial properties, (26) and they are very important compounds especially due to their relationship with compounds such as sex hormones (27).

Alkaloids have been associated with medicinal uses for centuries and one of their common biological properties is their cytotoxicity (28). Several workers have reported the analgesic (29), antispasmodic and antibacterial (30) properties of alkaloids. Glycosides are known to lower the blood pressure according to many reports (30). The results obtained in this study thus suggest the identified phytochemical compounds may be the bioactive constituents and this plant is proving to be an increasingly valuable reservoir of bioactive compounds of substantial medicinal merit.

Manniophyton fulvum Leaves extracts significantly $(\mathrm{p}<0.05)$ decreased the distance of gastrointestinal motility of rats from $100 \%$ (negetive control group) to $59.74 \%$ (aqueous) and $27.39 \%$ (ethanol), respectively (treatment groups). While loperamide $(1 \mathrm{mg} / \mathrm{kg})$, exhibited marked reduction, $32.20 \%$ with barium sulfate milk at $30 \mathrm{~min}$ study (Table I). Manniophyton fulvum leaves extract significantly $(\mathrm{p}<0.01)$ inhibited the mean number of defecation when compared to negetive control group $(84.61 \%)$ and treatment group $1(66.10 \%)$ and treatment group $2(47.06 \%)$ inhibition of the severity of diarrhea induced by castor oil was observed. The number of stools at 2 hours for ethanol extract treated group was significantly $(p<0.05)$ decreased as compared to control group. The percent inhibition of defecation of Manniophyton fulvum leaves ethanol extract (47.06\%) was found comparable to the effect of standard anti diarrheal drug loperamide (20.20\%) (Table II).

Table 1. Effect of the Manniophyton fulvum extracts on barium sulfate milk transit time

\begin{tabular}{|l|l|l|l|l|}
\hline GROUP & TREATMENT & $\begin{array}{l}\text { Length of intestine } \\
\text { (n/rats) }\end{array}$ & Distance covered & \% inhibition \\
\hline $\mathbf{1}$ & Control & $91.40 \pm 7.78$ & $91.40 \pm 7.78$ & $100(0)$ \\
\hline $\mathbf{2}$ & Loperamide $(\mathrm{mg} / \mathrm{kg})$ & $88.80 \pm 1.39$ & $28.60 \pm 2.96^{*}$ & $32.20(67.8)$ \\
\hline $\mathbf{3}$ & ALEMF $(\mathrm{mg} / \mathrm{kg})$ & $91.40 \pm 0.40$ & $54.60 \pm 4.03^{*}$ & $59.74(40.26)$ \\
\hline $\mathbf{4}$ & ELEMF $(\mathrm{mg} / \mathrm{kg})$ & $94.20 \pm 2.30$ & $25.80 \pm 1.36^{*}$ & $27.39(72.61)$ \\
\hline
\end{tabular}

Values are expressed as mean $\pm \mathrm{SEM} ; *$ Significance level $(p<0.05)$ 
Preliminary Phytochemical Screening and Antidiarrheal Properties of Manniophyton fulvum.

Table 1. Effect of the Manniophyton fulvum extracts on castor oil-induced diarrhoea

\begin{tabular}{|l|l|l|l|l|}
\hline GROUP & TREATMENT & $\begin{array}{l}\text { Faeces } \\
\text { (n/rats) }\end{array}$ & Wet feaces & $\begin{array}{l}\text { \% Anti-diarrhoeal } \\
\text { activity }\end{array}$ \\
\hline $\mathbf{1}$ & Control & $5.20 \pm 0.37$ & $14.80 \pm 0.37$ & $84.61(0)$ \\
\hline $\mathbf{2}$ & Loperamide $(1 \mathrm{mg} / \mathrm{kg})$ & $19.80 \pm 0.37$ & $4.60 \pm 0.25^{*}$ & $20.20(76.13)$ \\
\hline $\mathbf{3}$ & ALEMF $(400 \mathrm{mg} / \mathrm{kg})$ & $11.80 \pm 0.66$ & $7.80 \pm 0.58$ & $66.10(21.88)$ \\
\hline $\mathbf{4}$ & ELEMF $(400 \mathrm{mg} / \mathrm{kg})$ & $13.60 \pm 0.68$ & $6.40 \pm 0.40^{*}$ & $47.06(44.38)$ \\
\hline
\end{tabular}

Values are expressed as mean \pm SEM; Level of significance $(p<0.05)$

\section{KEY: ALEMF= AQUEOUS LEAVES EXTRACT OF Manniophyton fulvum \\ ELEMF $=$ ETHANOL LEAVES EXTRACT OF Manniophyton fulvum}

The leaves extracts showed a significant $(p<0.05)$ activity against castor oil-induced diarrhea. The result is comparable to the effect of widely used antidiarrheal drug loperamide when tested at $1 \mathrm{mg} / \mathrm{kg}$. Castor oil is made up of $90 \%$ ricinoleate (31) which is metabolized to ricinoleic acid. Ricinoleic acid causes the irritation and inflammation in the intestinal mucosa, leading to release of prostaglandins, which stimulate the net secretion of water and electrolytes into the small intestine (32). We speculate that the antidiarrheal effects of leaves extracts may be due to the inhibition of prostaglandin biosynthesis. Manniophyton fulvum leaves extract also significantly $(\mathrm{p}<0.05)$ decreased the distance of gastrointestinal motility of rats.

\section{Conclusion}

The result of this study reveals that the leaves extract of Manniophyton fulvum contains pharmacologically active substances with antidiarrheal properties. These properties could be a potential source of modern pharmaceutical products. Further investigation is necessary to isolate, identify and characterize the different active compounds found in the extract and to elucidate their mode of action.

\section{ETHICAL APPROVAL}

All authors hereby declare that all experiments have been examined and approved by the appropriate ethics committee and have therefore been performed in accordance with the ethical standards laid down in the 1964 declaration of Helsinki.

\section{References}

[1]. Carlos CC, Saniel MC. Etiology and epidemiology of diarrhea. Phillips J Microbio Infect Dis. 1990; 19: 51-53.

[2]. Ojewole JAO. Evaluation of antidiarrheal, anti-inflammatory and antidiabetic properties of Sclerocarya birrea (A. Rich.) Hochst. stem bark aqueous extract in mice and rats. Phytotherapy Res. 2004; 18: 601-08.

[3]. Atta AH, Mouneir SM. Antidiarrheal activity of some Egyptian medicinal plant extracts. J Ethnopharmacol. 2004 ; 92 : 303-09.

[4]. Burkill, H.M. The useful plants of West Tropical Africa. 2nd Edition. Volume 2, Families E-I. Royal Botanic Gardens, Kew, Richmond, United Kingdom. 1994;636pp.

[5]. Nia, R., Paper, D.H., Franz, G., Essien, E.E., Muganza, M. \& Hohmann, G. Anti-oxidant and anti-inflammatory activity of Manniophyton fulvum. Acta Horticulturae, 2005; 678: 97-101.

[6]. Ojieh A E., Adegor E C., and Ewhre O. L., Preliminary Phytochemical Screening, Analgesic and Anti-inflammatory Properties of Celosia isertii. European Journal of Medicinal Plants. 2013; 3(3): 309-320

[7]. Brain KR, Turner TD. Wright - Scientechnica. 1st Ed. Bristol: Practical evaluation of phytopharmaceuticals. $1975 ; 144$.

[8]. Ciulei I. Methodology for analysis of vegetable drugs. Romania: United Nations Industrial Development Organisation. 1981;17-25.

[9]. Dewick, PM. Tumor inhibition from plants: Trease GE. Evans WC. Pharmacognosy. 1996;11.

[10]. Ciulei I. Methodology for the Analysis of Vegetable Drugs. Publication of UNIDO, Romani. 1997;64-67.

[11]. Harborne JB. A guide to modern technique of plant analysis. London: Chapman and Hill. Phytochemical methods. 1973;279.

[12]. Van Burden TP, Robinson WC. Formation of complexes between protein and tannin acid. J Agric Food Chem. 1981;1:77.

[13]. Boham BA, Kocipai-Abyazan R. Flavonoids and condensed tannin from leaves of Hawaiian vaccinium and V. Calycinium. Paciffic Sci. 1974;48:458-463.

[14]. Chatterjee TK. Handbook on laboratory mice and rats. 1st ed. Kolkata, Department of Pharmaceutical Technology, Jadavpur University, 1993, p 157.

[15]. Shoba FG, Thomas M. Study of antidiarrheal activity of four medicinal plants in castor oil-induced diarrhea. J Ethnopharmacol. 2001; 76: 73-76.

[16]. Aiyegroro OA, Okoh AI. Preliminary phytochemical screening and in vitro antioxidant activities of aqueous extract of Helichrysum longifolium DC. BMC compl. And Alt. Med. 2001;10:21.

[17]. Singh R, Singh SK, Arora S. Evaluation of antioxidant potential of ethyl acetate extract/fractions of Acacia auriculiformis A. Cunn. Food Chem. Toxicol. 2007;45:1216-1223.

[18]. Del-Rio A, Obdululio BG, Casfillo J, Main FG, Ortuno A. Uses and properties of citrus flavonoids. J. Agric. Food Chem. 1997;45:4505-4515.

[19]. Parekh J, Chanda S. Phytochemicals screening of some plants from western region of India. Plant Arch. 2008;8:657-662.

[20]. Krings U, Berger RG. Antioxidant activity of roasted foods. Food Chem. 2001;72:223-229.

[21]. Marjorie C. Plant products as antimicrobial agents. Clincal Microbiol. Rev. 1996;12:564-582.

[22]. Salah N, Miller NJ, Pagange G, Tijburg L, Bolwell GP, Rice E, Evans C. Polyphenolic flavonoids as scavenger of aqueous phase radicals as chai breaking antioxidant. Arc. Biochem. Broph. 1995;2:339-346.

[23]. Okwu DE. Phytochemicals and vitamin content of indigenous species of southeastern Nigeria. J.Sustain. Agric. Environ. 2004;6(1):30-37.

[24]. Just MJ, Recio MC, Giner RM, Cueller MU, Manez S, Billia AR, Rios JL. Antiinflammatory activity of unusual lupine saponins from Bupleurum fruticescens. 1998;64:404-407. 
[25]. Sodipo OA, Akiniyi JA, Ogunbamosu JU. Studies on certain on certain characteristics of extracts of bark of Pansinystalia macruceras (K schemp) picrre Exbeille. Global J. Pure Appl. Sci. 2000;6:83-87.

[26]. Cowan MM. Plant products as antimicrobial agents. Clin. Microbiol. Rev. 1999;564-582.

[27]. Nobori T, Miurak K, Wu DJ, Takabayashik LA, Carson DA. Deletion of cyclindependent kinase-4 inhibitor gene in multiple human cancers. Nature. 1994;46:753-756.

[28]. Antherden LM. Textbook of Pharmaceutical Chemistry, 8edn, Oxford University Press, London. 1969;813-814.

[29]. Okwu DE, Okwu ME. Chemical composition of Spondias mombin linn. Plant parts. J. Sustain. Agric. Environ. 2004;6(2):140-147.

[30]. Nyarko AA, Addy ME. Effects of aqueous extract of Adenia cissampeloides on blood pressure and serum analyte of hypertensive patients. Phytotherapy Res. 1990;4(1):25-28.

[31]. Mekeon TA, Lin A, Stafford AE. Biosynthesis of ricinoleate in castor oil. Adv Exp Med Biol. 1999, pp. 46437-47.

[32]. Luderer JR, Dermers IM, Hayes AT. Advances in prostaglandin and thromboxane research. New York, Raven Press, 1980, pp 163338 . 